ОСОБЛИВОСТІ ЗАГАЛЬНОЇ ПЕДАГОГІЧНОЇ ПІДГОТОВКИ БАКАЛАВРІВ ФІЗИЧНОГО ВИХОВАННЯ В АВСТРІЇ

\title{
PECULIARITIES OF GENERAL PEDAGOGICAL TRAINING OF BACHELORS IN PHYSICAL EDUCATION IN AUSTRIA
}

\begin{abstract}
Метою статmі є вивчення організації та особливостей загальної педагогічної підготовки бакалаврів фрізичного виховання в Австрії. Для досягнення мети використовувався комплекс теоретичних методів дослідження: аналіз, синтез, зіставлення, систематизація, узагальнення, логіко-теоретичний аналіз. Професійна підготовка педагогічних кадрів з фрізичної культури і спорту в Австрії здійснюється в універсиmemax ma вищих педагогічних школах у межах освітньої галузі «Педагогічна освіта» напряму підготовки «Загальна освіта» спеціальності «Рух і спорт». Навчальні плани професійної підготовки бакалаврів зі спеціальності «Рух і спорт» австрійських вищих навчальних закладів передбачають побудову освітнього процесу за принципом спіралі, згідно з яким окремі предметні галузі, теми, проблеми повторюються протягом усього періоду підготовки на щораз вищому рівні складності в диференційованій формі. Каркас цієї складної конструкції утворюють модулі загальної педагогічної підготовки: професійна ініціація у сфреру освіти; навчання, викладання та дослідження в диверсиорікованому контексті; діагностика, консультування, виховання, навчання та оцінювання; професіоналізація педагога у галузі шкільної освіти; інтеграція та поглиблення просресійних компетенцій. Кожен елемент структури загальнопедагогічної підготовки майбутніх учителів спорту у вищих навчальних закладах Австрії свідчить про їх цільову спрямованість на забезпечення грунтовноі базової педагогічної освіти у взаємозв'язку теоретичного і практичного компонентів. Усе це слугує надійною основою для оволодіння майбутніми вчителями спорту і фрізичної культури базовими інваріантними психолого-педагогічними знаннями й уміннями, які визначають здатність до розв'язання великого діапазону освітньо-виховних завдань у різних педагогічних системах, та набуття сукупності загальнолюдських, соціально та професійно важливих якостей, необхідних для подальшої успішної педагогічної діяльHOCmi.

Ключові слова: підготовка вчителів, бакалавр, фрізичне виховання, педагогічна підготовка, Австрія.
\end{abstract}

2019-13-2-7

Романчук O.B.,

канд. фрілол. наук, доцент,

завідувач кафедри української

та іноземних мов

Львівського державного

університету фрізичної культури

імені Івана Боберського
The article deals with peculiarities of general pedagogical training of bachelors in physical education in Austria. The Austrian experience of teaching staff training in sports and physical education is of particular interest, primarily as a source of valuable ideas and innovative approaches to develop an effective professional training system for specialists in the physical education preparation. The aim of the article is to study the organization and features of genera teacher training for bachelors of physical education in Austria. To achieve the aim, a set of theoretical methods of research has been used: analysis, synthesis, comparison, systematization, generalization, logical and theoretical analysis. Professional training of pedagogical staff in physical education and sports in Austria is carried out at universities and higher pedagogical schools within the educational field "Pedagogical Education" in the direction of training "General Education" specialty "Movement and Sport". The training of specialists in physical education in Austrian universities covers a maximum of 8 semesters, and the volume of 240 ECTS credits, with one ECTS credit equal to 25 academic hours. According to the professional competence, profile of the future bachelor of pedagogical specialty "Movement and Sport", the structure of the process of professional training includes the following components: general-pedagogical preparation in the amount of 40 ECTS credits; subject training (Specialty 1 "Movement and Sports" and Specialty 2 (at the student's choice) with a maximum volume of 80 ECTS credits; subject-didactic training with minimum 20 ECTS credits; pedagogical-practical training within the framework of general-pedagogical training 23 ECTS credits and subject-didactic training in the volume of 10 ECTS credits. General pedagogical preparation forms the core of the system of professional education of teaching staff in physical education and sports in Austrian higher education institutions, providing, first of all, the personal development of the future teacher, the formation of his/her scientific and professional outlook, the development of basic pedagogical knowledge and skills.

Key words: teachers training, bachelor, physical education, pedagogical training, Austria.
Постановка проблеми у загальному вигляді. Збереження і зміцнення здоров'я молодого покоління, його повноцінний фрізичний розвиток актуалізують розробку і застосування більш ефективних фрорм фрізкультурно-оздоровчої та спортивної роботи з дітьми й молоддю, що неодмінно передбачає якісну освіту висококваліфрікованих педагогічних кадрів. Відповідальність за підготовку нового покоління фрахівців з фрізичного виховання, зміст і рівень кваліфрікації яких адекватні інноваціям, що відбуваються в галузі фрізичної культури і спорту та освітньої сорери, покладається передовсім на систему вищої освіти. Іїі неперервна модернізація є запорукою опанування майбутніми педагогами у сорері спорту і фрізичної культури комплексом знань, умінь і навичок, їхнього профресійного розвитку, орормування профресійних інтересів, мотивів та ціннісних орієнтацій, що завершується виробленням стійкої професійно-педагогічної позиції та профресійної компетентності як інтегральної якості фрахівця з фрізичного виховання. 3 огляду на зазначене австрійський досвід організації вищої освіти педагогічних кадрів зі спорту 
і фрізичної культури викликає особливе зацікавлення, передовсім як джерело цінних ідей і новаторських підходів до розбудови системи ефрективної профресійної підготовки фрахівців 3 фрізичного виховання дітей і молоді.

Аналізуючи літературу 3 проблеми дослідження, зазначимо, що особливо важливими для нашої розвідки є праці з педагогічної освіти за кордоном, зокрема ті, в яких висвітлюється австрійський досвід профресійної підготовки педагогічних кадрів. У працях Л. Пуховської [3], Т. Кристопчук [1], М. М'ясковського [2] докладно розглядаються історичні аспекти, сучасний стан та тенденції подальшого розвитку системи педагогічної освіти Австрії.

Метою статті $€$ вивчення організації та особливостей загальної педагогічної підготовки бакалаврів фрізичного виховання в Австрії. Для досягнення мети використовувався комплекс теоретичних методів дослідження: аналіз, синтез, зіставлення, систематизація, узагальнення, логіко-теоретичний аналіз.

Виклад основного матеріалу. Професійна підготовка педагогічних кадрів 3 фрізичної культури і спорту в Австрії здійснюється в університетах та вищих педагогічних школах у межах освітньої галузі «Педагогічна освіта» напряму підготовки «Загальна освіта» спеціальності «Рух і спорт». Процес профресійно-педагогічної освіти за цією спеціальністю охоплює два етапи: бакалаврат та магістратуру. Етап бакалаврату спрямований на фрормування широкого спектра особистісних і професійних компетенцій майбутніх учителів фрізичної культури і спорту. Зокрема, прогнозованими результатами бакалаврської програми зі спеціальності «Рух і спорт» у чинних навчальних планах визначено:

- загально-профресійні компетенції;

- науково-дослідницькі компетенції;

- комунікативно-соціальні компетенції;

- фахові або предметні компетенції;

- фрахово-дидактичні компетенції [4; 5; 6; 7].

Підготовка фрахівців 3 фрізичного виховання у вищих навчальних закладах Австрії на етапі бакалаврату передбачає формування базових соціально-особистісних, загальнокультурних загальнонаукових, а також професійних компетенцій з огляду на відповідну предметну галузь і професійний профіль. На цьому етапі акцент зроблено на різнобічному розвитку особистості майбутнього вчителя спорту. 3 огляду на зазначене бакалавр педагогічної освіти цього напряму і профрілю має володіти цілою системою якостей, знань, умінь і навичок, що характеризує його готовність до педагогічної діяльності 3 дітьми і молоддю.
Набуттю цих компетенцій і підпорядкований весь процес профресійної підготовки вчительських кадрів з фрізичної культури і спорту на етапі бакалаврату в системі вищої освіти Австрії. Його тривалість охоплює переважно 8 семестрів, а обсяг - 240 кредитів ЄКТС, при цьому 1 кредит ЄКТС дорівнює 25-годинному навчальному навантаженню. Відповідно до профрілю професійної компетентності майбутнього бакалавра із педагогічної спеціальності «Рух і спорт» структура процесу професійної підготовки включає такі складники:

- загально-педагогічна підготовка обсягом 40 кредитів ЄКТС;

- предметна підготовка (спеціальність 1 «Рух і спорт» та спеціальність 2 (за вибором студента) максимальним обсягом по 80 кредитів EKTC;

- предметно-дидактична підготовка із двох спеціальностей мінімальним обсягом по 20 кредитів ЄКТС;

- педагогічно-практичні студії в рамках загальнопедагогічної підготовки обсягом 23 кредити ЄКТС та предметно-дидактичної підготовки обсягом 10 кредитів ЄКТС [4; 5; 6; 7].

Навчальні плани професійної підготовки бакалаврів зі спеціальності «Рух і спорт» австрійських вищих навчальних закладів передбачають побудову освітнього процесу за принципом спіралі, згідно з яким окремі предметні галузі, теми, проблеми повторюються протягом усього періоду підготовки на щораз вищому рівні складності в диореренційованій формі. Завдяки послідовному розширенню та поглибленню базових профресійних знань і досвіду в навчальному процесі і забезпечується інтегративна основа педагогічного мислення та профресійної компетентності майбутнього вчителя спорту.

Каркас цієї складної конструкції утворюють модулі загальної педагогічної підготовки, що виконує координуючу фрункцію в комплексній системі профресійної підготовки майбутнього вчителя спорту, фрормує його особистісну позицію і спрямованість на педагогічну професію. Загальнопедагогічна підготовка в структурі професійної освіти фрахівців з фрізичного виховання - це логічно структурована система навчальних модулів, спрямована на засвоєння педагогічних знань, розвиток відповідних умінь і навичок, набуття досвіду науково-пошукової діяльності в освітній галузі, а також фрормування ціннісних орієнтацій і зорієнтованості на педагогічну діяльність. Розглянемо для прикладу особливості загальнопедагогічної підготовки майбутніх учителів спорту на етапі бакалаврату відповідно до чинного навчального плану Інсбрукського університету (табл. 1). 
Структура та обсяг загальнопедагогічної підготовки бакалаврів зі спеціальності «Рух і спорт» (на основі навчального плану Інсбрукського університету)

\begin{tabular}{|c|c|c|}
\hline \multicolumn{2}{|c|}{ Назва модуля } & $\begin{array}{c}\text { Обсяг } \\
\text { (кредити } \\
\text { єкТС) }\end{array}$ \\
\hline 1. & Продесійна ініціація у сорері освіти & 7,5 \\
\hline 2. & $\begin{array}{c}\text { Навчання, викладання та дослідження } \\
\text { в диверсифрікованому контексті }\end{array}$ & 7,5 \\
\hline 3. & $\begin{array}{c}\text { Діагностика, консультування, } \\
\text { виховання, навчання та оцінювання }\end{array}$ & 7,5 \\
\hline 4. & $\begin{array}{c}\text { Професіоналізація педагога } \\
\text { у галузі шкільної освіти }\end{array}$ & 10 \\
\hline 5. & $\begin{array}{c}\text { Інтеграція та поглиблення } \\
\text { продесійних компетенцій }\end{array}$ & 2,5 \\
\hline 6. & $\begin{array}{c}\text { Актуальні теми педагогічних } \\
\text { та освітніх досліджень }\end{array}$ & 5 \\
\hline
\end{tabular}

Розглянемо докладніше завдання і зміст згаданих модулів загальноосвітньої підготовки майбутніх учителів спорту і фрізичної культури. Так, перший модуль «Профресійна ініціація у сферу освіти» спрямований на усвідомлення значення школи як освітнього інституту та набуття базових знань з питань навчання і виховання. Модуль забезпечує ознайомлення 3 традиційними та альтернативними концепціями навчання, підходами і методами реалізації педагогічного процесу, структурою й організацією системи освіти. Також у рамках модуля передбачено ознайомлення зі специфрікою профресії педагога, його обов'язками, функціями, реаліями профресійної практики на основі безпосередніх спостережень в освітніх установах. Інтегрованим компонентом модуля $\epsilon$ і набуття першого досвіду із планування і проведення фррагментів занять, як-от: презентації навчального матеріалу чи конструювання навчальних ситуацій. Досягнення названих завдань і цілей модуля забезпечується у процесі вивчення курсу «Школа як освітній інститут та роль педагогічного працівника» (4 кредити ЄКТС). Тематика курсу сягає від організації системи шкільної освіти до професійних обов'язків сучасного педагога. Для доповнення теоретичного матеріалу курсу в рамках модуля передбачено й ознайомлювальну шкільну практику (3,5 кредиту $€ K T C)$. Ії метою визначено забезпечення для майбутніх педагогів можливостей для занурення у реалії професійного життя і діяльності вчителя [5].

Другий модуль загальнопедагогічної підготовки майбутнього вчителя спорту під назвою «Навчання, викладання та дослідження в диверсифікованому контексті» спрямований на ознайомлення студентів-бакалаврів спеціальності «Рух і спорт» із дидактичними теоріями і концепціями, специорікою побудови й організації навчально-виховного процесу в гетерогенних за найрізноманітнішими ознаками (вік, стать, національність, мова, релігія тощо) групах і класах, усвідомлення ними перспектив і меж педагогічної діяльності з огляду на різноманітні соціокультурні, освітньо-політичні, матеріально-економічні умови, оволодіння підходами і методологією дослідження педагогічних явищ тощо. Модуль містить курс «Навчання і викладання в диверсифрікованому контексті» (4 кредити ЄКТС), проблематика якого охоплює питання про освітні процеси крізь призму соціальних проблем, потреб і перспектив, психологічні особливості пізнавальної діяльності, педагогічні основи навчання і виховання. До складу модуля входить також курс «Педагогічні дослідження та розвиток школи і освіти» (3,5 кредиту ЄКТС), завданнями якого $€$ освоєння методології і термінології науковопедагогічних досліджень, обговорення поточних результатів комплексних наукових студій з освітніх проблем, осмислення підходів і методів забезпечення якості шкільної освіти тощо [5].

Третій модуль «Діагностика, консультування, виховання, навчання та оцінювання» акцентує увагу майбутніх педагогів на питаннях педагогічної взаємодії і комунікації, зокрема організації навчально-виховного процесу відповідно до ідей особистісно орієнтованої освітньої парадигми, принципів суб'єкт-суб'єктних відносин. Очікуваним результатом освоєння цього модуля визначено здатність до самостійного планування і проведення різних елементів навчального заняття на основі використання широкого розмаїття методів навчально-виховної роботи, відповідних поставленим освітнім цілям і завданням. Основною структурною одиницею модуля $є$ курс «Діагностика та консультування» (4 кредити ЄКТС), проблематика якого спрямована на ознайомлення майбутніх учителів із теоретичними основами та методичними підходами й інструментами педагогічної діагностики і консультування, концепціями і стратегіями комунікативної діяльності під час освітнього процесу, способами і можливостями попередження і подолання кризових явищ, конфрліктних ситуацій, виявів насильства тощо. Важливим складником модуля $є$ також курс «Освіта та контроль успішності» (3,5 кредиту ЄКТС), що передбачає, з одного боку, вивчення питань теорії та організації навчання і виховання крізь призму формальної освіти, обговорення актуальних психологічних і педагогічних концепцій, пізнання моделей побудови освітнього процесу, а з іншого безпосередню участь у плануванні і проведенні елементів заняття в освітніх установах з опорою на прийняті освітні стандарти, практичну апробацію засвоєних знань і вмінь у реальних умовах шкільного навчання і виховання [5].

Четвертий модуль «Профеесіоналізація педагога у галузі шкільної освіти» реалізує завдання поглибленого ознайомлення майбутніх учителів 3 концепціями і підходами до планування й організа- 
ції навчально-виховного процесу та об'єктивного оцінювання його результатів. Зокрема, тут ідеться про фрормування вмінь і навичок ефективного добору методів, засобів, технологій навчального процесу відповідно до його цілей у динамічних ситуаціях шкільного життя та освіти. Особливими тематичними акцентами модуля постають питання про динаміку розвитку учнівських колективів, структури й організації соціальних відносин у межах учнівського колективу, ефективні фрорми співпраці та взаємодії школярів у межах колективу тощо. Усе це становить основу для набуття знань про шляхи і можливості організації освітньої траєкторії як учнівського колективу загалом, так і кожного школяра зокрема та вмінь ефективно використовувати широкий діапазон методів і фрорм організації освітнього процесу 3 огляду на розмаїття ситуацій шкільного й особистісного життя учнів. На реалізацію цих завдань модуля спрямовано курс «Профресійні знання і вміння педагога» (10 кредитів ЄКТС). Його перша частина - теоретична (3 кредити ЄКТС) - передбачає опрацювання низки тем, як-от: школа як освітній інститут, інноваційні концепції і технології навчання і виховання, навчання і виховання у диверсифікованих шкільних колективах, індивідуалізація та диференціація освітнього процесу, особистісно орієнтована освіта тощо. Друга частина - практична (7 кредитів ЄКТС) - це власне педагогічна практика у різних типах шкіл Австрії першого і другого ступенів, спрямована на набуття безпосереднього досвіду з планування й організації освітнього процесу в реальних умовах професійної педагогічної діяльності, саморефлексію й самооцінку власних знань і можливостей [5].

П'ятий модуль «нтеграція та поглиблення професійних компетенцій» має на меті спонукання майбутніх педагогів до постійної ресрлексії над власними професійними знаннями, вміннями, досвідом, мотивації до професійного самовдосконалення, фрормування здатності до ефективної організації процесу подальшого професійного становлення і розвитку. Особлива увага в межах модуля приділяється розвитку критичного мислення майбутніх педагогів, об'єктивної оцінки освіти і школи як галузей майбутньої профресійної діяльності, прогнозування перспектив їхнього подальшого розвитку. Модуль містить лише один курс «Інтеграція професійних компетенцій» (2,5 кредиту ЄКТС), проблематика якого орієнтує на ретроспективний огляд і рефлексію власного шляху професійного становлення, починаючи 3 аналізу моменту вибору профресії педагога і до окреслення перспектив самореалізації у її межах, а також на осмислення процесу професіоналізації педагога крізь призму освітньо- і профресійнотеоретичних концепцій та усвідомлення поточного стану набутих професійних компетенцій і визна- чення цілей свого подальшого профресійного саморозвитку. Курс акцентує увагу на основних проблемах педагогічної професії, як-от боротьба зі стресовими моментами, розв'язання конфрліктних ситуацій, подолання невпевненості у собі тощо [5].

Останній модуль загальнопедагогічної підготовки «Актуальні теми педагогічних та освітніх досліджень» слугує задоволенню індивідуальних запитів майбутніх учителів щодо вдосконалення професійної компетентності та подальшого професійного становлення. Так, на вибір студентам пропонується низка курсів (кожен обсягом 2,5 кредиту ЄКТС), що відображають найбільш актуальні проблеми сучасної шкільної освіти. Наприклад, у межах курсу «ґендерні питання і шкільна освіта» розглядаються питання впровадження ґендерного підходу в навчально-виховний процес та теорії і методики ґендерного виховання дітей і молоді. Курс «ннклюзія і гетерогенність у системі шкільної освіти» актуалізує проблеми інклюзивної освіти та забезпечення належних освітніх можливостей для дітей $з$ особливими потребами, їх інтеграції до учнівської спільноти. Курс «Багатомовність і мультикультурність у школі» порушує питання включення до спільного освітнього простору представників різних соціальних груп, тобто дітей із соціальними, мовними чи культурними відмінностями. Подібна проблема закладена в основу ще одного курсу «Плюральність світоглядів», що презентує питання освіти і виховання дітей і молоді з огляду на їхню світоглядно-релігійну неоднорідність [5].

Висновки. Здійснений аналіз доводить, що загальнопедагогічна підготовка становить ядро системи професійної освіти педагогічних кадрів 3 фрізичної культури і спорту в австрійських вищих навчальних закладах, забезпечуючи насамперед особистісний розвиток майбутнього вчителя, формування його науково-профресійного світогляду, освоєння базових педагогічних знань і вмінь. 3 аналізу змісту модулів і навчальних курсів, через які реалізується загальнопедагогічна підготовка, вона постає як процес становлення сукупності якостей професіонала, здатного успішно створювати соціально-виховні системи й ефективно виконувати завдання гармонійного і різнобічного розвитку і виховання дітей і молоді.

Загальнопедагогічна підготовка бакалаврів зі спеціальності «Рух і спорт» в австрійських вищих навчальних закладах спрямована на засвоєння основ сучасної педагогічної науки, розвиток педагогічного мислення, набуття базових умінь і навичок навчально-виховної роботи. Модулі загальнопедагогічної підготовки розкривають наукові, концептуальні основи навчання і виховання у сучасній школі, ефективні методи і технології їх здійснення, конструктивні шляхи і способи забезпечення якості освіти. Таким чином, вона кон- 
центрує у собі ключові теоретичні і методологічні положення педагогічної науки, основні питання організації навчально-виховного процесу у сучасній школі крізь призму соціальних, культурних, політичних тощо тенденцій. Усе це, зрештою, і забезпечує орормування в студентів комплексної готовності до здійснення соціально-педагогічних фрункцій учителя.

Помітною особливістю загальнопедагогічної підготовки майбутніх учителів спорту в австрійських вищих навчальних закладах $€$ наявність варіативного компонента у формі альтернативних навчальних курсів, що дають змогу диференціювати зміст профресійної освіти з урахуванням їх запитів та зацікавлень відповідно до найбільш нагальних проблем і завдань професійної діяльності сучасного педагога. Курси за вибором у рамках останнього модуля загальнопедагогічної підготовки мають теоретико-методологічну спрямованість та передбачають поглиблене вивчення актуальних проблем освіти і педагогіки, залучення майбутніх учителів спорту до дослідницької діяльності та фрормування в них творчого підходу до просресійної діяльності.

Отже, характеристика фрункціонального призначення кожного елемента структури загальнопедагогічної підготовки майбутніх учителів спорту у вищих навчальних закладах Австрії свідчить про їх цільову спрямованість на забезпечення ґрунтовної базової педагогічної освіти у взаємозв'язку теоретичного і практичного компонентів. Усе це слугує надійною основою для оволодіння май- бутніми вчителями спорту і фрізичної культури базовими інваріантними психолого-педагогічними знаннями й уміннями, які визначають здатність до розв'язання великого діапазону освітньо-виховних завдань у різних педагогічних системах, та набуття сукупності загальнолюдських, соціально та професійно важливих якостей, необхідних для подальшої успішної педагогічної діяльності.

\section{БІБЛІОГРАФІЧНИЙ СПИСОК:}

1. Кристопчук Т.Є. Педагогічна освіта в країнах Європейського Союзу. Рівне : Волинські обереги. 2013. 484 C.

2. М'ясковський М.Є. Педагогічна освіта Австрії XIX - початку XX ст. : автореф. дис... канд. пед. наук : 13.00.01.Тернопіль, 2009. 20 с.

3. Пуховська Л.П. Профресійна підготовка вчителів у Західній Європі: спільність і розбіжності. Київ : Вища шк., 1997. 179 с.

4. Allgemeines Curriculum für das Bachelorstudium zur Erlangung eines Lehramts im Bereich der Sekundarstufe (Allgemeinbildung) im Verbund NordOst. Mitteilungsblatt der Universität Wien. 2014. St. 39. S. 1-15.

5. Curriculum für das Bachelorstudium Lehramt Sekundarstufe (Allgemeinbildung), Mitteilungsblatt der Leopold-Franzens-Universität Innsbruck. 2015. St. 64. S. 1-237.

6. Curriculum für das Bachelorstudium Lehramt Sekundarstufe (Allgemeinbildung). Mitteilungsblatt der Karl-Franzens-Universität Graz. 2017. St. 38. S. 1-666.

7. Curriculum für das Bachelorstudium Lehramt Sekundarstufe (Allgemeinbildung). Mitteilungsblatt der Paris Lodron-Universität Salzburg. 2017. St. 63. S. 1-612. 